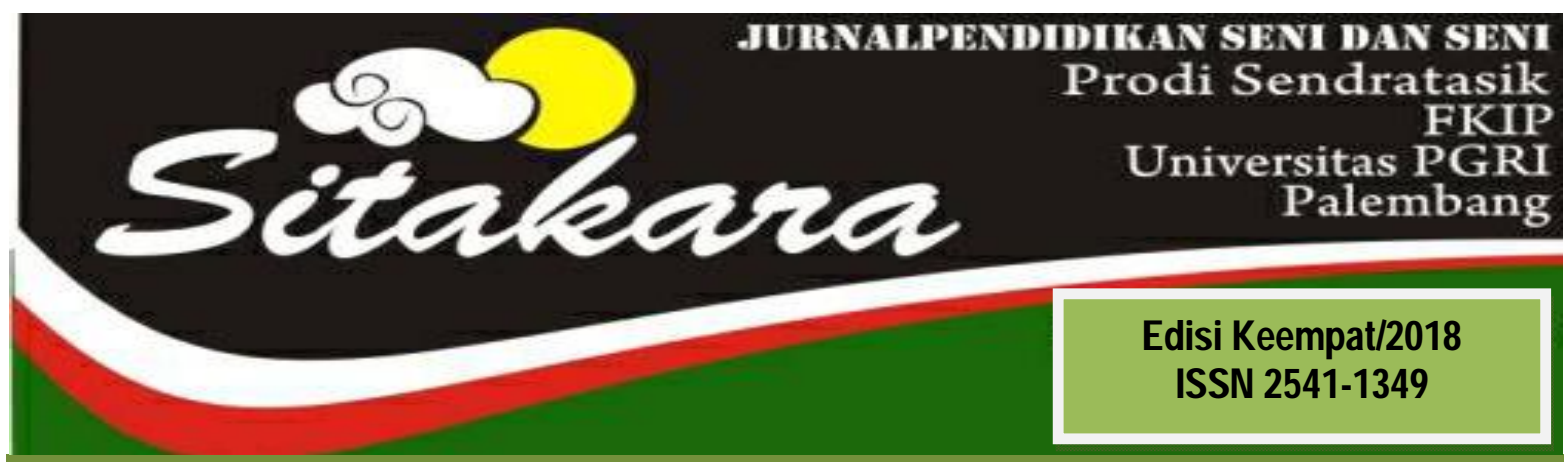

Objektifitas Imajinatif Dalam Pertunjukan Teater

Mohammad A rfani

Makna Estetis Dalam Simbol Tatto

Novdaly Fillamenta

Desain A tas (Air D esign) D alam Dimensi Estetik Pertunjukan Karya Tari

Efita Elvandari

Pengaruh M etode D emonstrasi D alam Pembelajaran Tari Burung Bermain

Pada Kegiatan Ekstrakurikuler D i SM P N egeri 36 Palembang

Ria Moulina A driamul

Gerak: Perjalanan D ari M otif Ke Komposisi Tari

Rully Rochayati

Sastra Lisan Dalam Kesenian Saluang D endang Sumatera Barat

Nofroza Yelli

Rangsang A udio Sebagai M otivasi Pada Penciptaan Karya

Tari Tunggu Tubang Dalam Pembelajaran Koreografi di Universitas

PG RI Palembang

Treny Hera

M otif Bungo Pacik Pada Tenunan Songket Palembang

Mainur

Konsep Kreatifitas Wallas D alam Proses Penciptaan Tari Tepak Keraton

Nurdin

A nalisis Bentuk Gerak Tari Turak Di Sanggar Studio Lingga

Kota Lubuklinggau

Sisca Fitriani

Bentuk Figur Tokoh Wayang Kulit Palembang

Robert Budi Laksana 


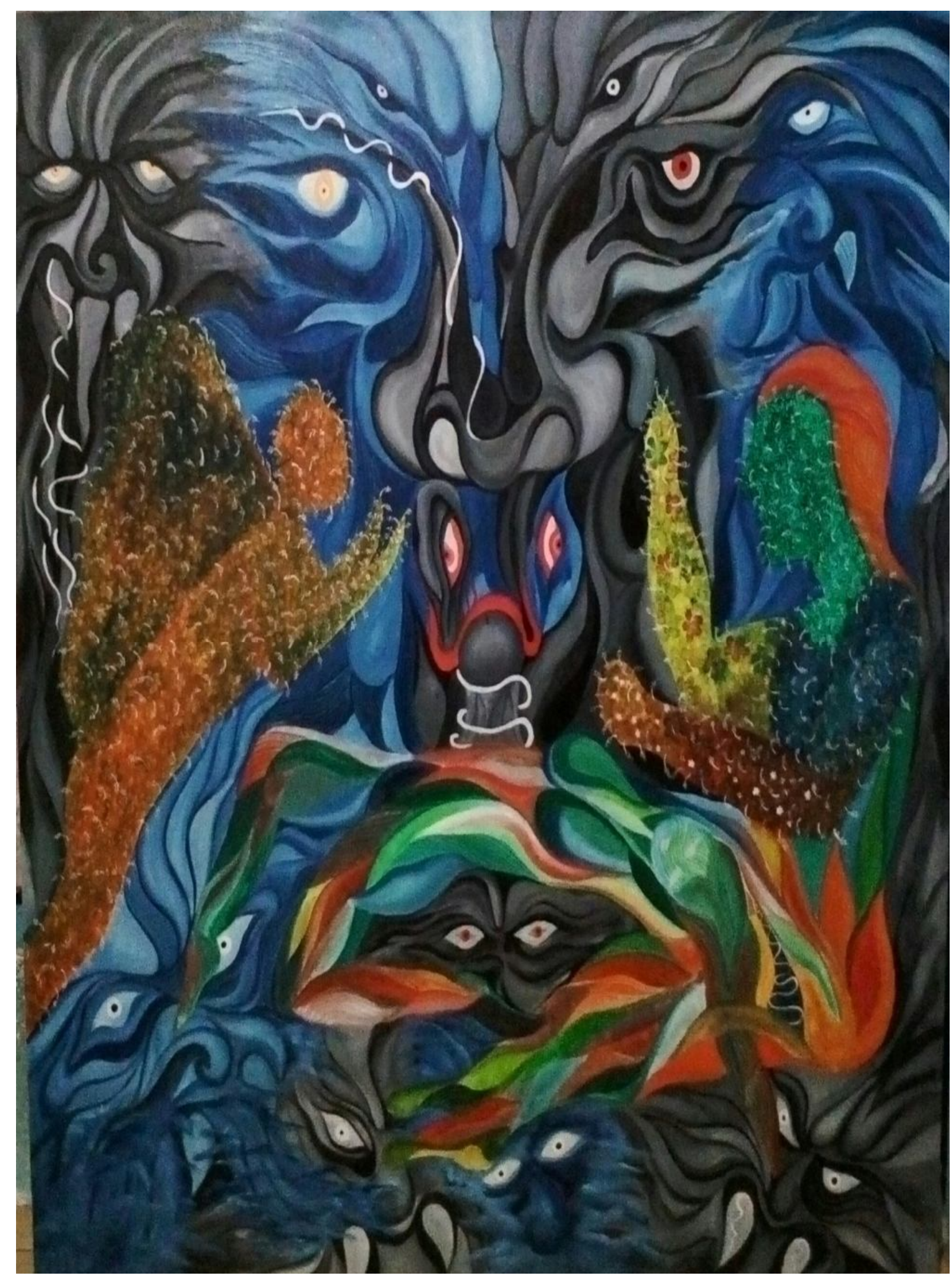




\section{SITAKARA}

\section{JURNAL PENDIDIKAN SENI DAN SENI BUDAYA}

Edisi 4, Februari 2018

\section{DEWAN REDAKSI}

1. PenanggungJawab

2. KetuaDewan Redaksi

3. WakilDewanRedaksi

4. Sekretaris

5. PenyuntingPelaksana

6. Penyunting Ahli

7. Setting
:

: Dra. Andinasari, M.M., M.Pd.

: RullyRochayati, M.Sn

: Nofroza Yelli, M.Sn

: Treny Hera, S.Pd., M.Sn

: 1. Efita Elvandari, M.Sn

2. Arfani, S.Pd., M.Sn

: 1. Prof. Dr. Triyono Bramantyo, P.Hd (ISI Yogyakarta)

2. Dr. DessyWardiah, M.Pd (UPGRI)

3. Dr. Slamet, M.Hum (ISI Surakarta)

4. Yayan Hariyansyah, M.Sn (UIGM)

: 1. Mainur, S.Pd.,M.Sn

2. I Komang Kerta Yana, S.Si

\section{AlamatRedaksi}

Program StudiPendidikanSendratasik JurusanPendidikanKesenian FKIP Universitas PGRI Palembang Jl. A. YaniLorongGotongRoyong 9/10 Ulu Palembang Telp. 0711-510043 Fax. 0711-514782 E-mail: jurnalsitakarasendratasik@yahoo.com 


\section{DAFTAR ISI}

Objektifitas Imajinatif D alam Pertunjukan Teater

M ohammad A rfani

Makna Estetis D alam Simbol Tatto

Novdaly Fillamenta

D esain A tas (Air D esign) D alam D imensi Estetik Pertunjukan Karya Tari

Efita Elvandari

Pengaruh M etode D emonstrasi D alam Pembelajaran Tari Burung Bermain 25 Pada Kegiatan Ekstrakurikuler Di SM P N egeri 36 Palembang

Ria M oulina Adriamul

G erak: Perjalanan D ari M otif Ke Komposisi Tari

Rully Rochayati

SastraL isanD al amK esenianSaluangD endang Sumatera Barat

N ofroza Yelli

Rangsang Audio Sebagai M otivasi Pada Penciptaan Karya

Tari Tunggu Tubang Dalam Pembelajaran Koreografi di Universitas

PG RI Palembang

Treny Hera

Motif Bungo Pacik Pada Tenunan Songket Palembang

Mainur

Konsep K reatifitas Wallas D alam Proses Penciptaan Tari Tepak Keraton N urdin

Analisis Bentuk G erak Tari Turak Di Sanggar Studio Lingga

Kota Lubuklinggau

Sisca Fitriani

BentukFigurT okohWayangKulit Palembang 


\title{
DESAIN ATAS (AIR DESIGN) DALAM DIMENSI ESTETIK PERTUNJUKAN KARYA TARI
}

\author{
Oleh: \\ Efita Elvandari \\ (Program Studi Pendidikan Sendratasik FKIP Universitas PGRI Palembang)
}

\begin{abstract}
ABSTRAK
Tari sebagai sebuah produk karya seni, apapun jenis dan bentuknya tentunya akan mengandung suatu nilai keindahan. Nilai keindahan ini seyogyanya dihadirkan dalam setiap penampilan karya tari, sehingga tidak ada kesan bahwa sajian sebuah karya tari bukan hanya sekedar bentuk rangkaian gerak tubuh semata. Salah satu hal yang membuat penikmat tari dapat merasakan keindahan sebuah gerak tari adalah ketika pelakunya (penari) mampu menarikan dengan kekuatan, kelenturan, keseimbangan, dan koordinasi yang sempurna sehingga rasa gerak yang dilakukan dapat dirasakan oleh penonton. Esensi dan makna gerak menjadi jiwa dunia tari dan manusianya, sehingga segala hal yang berkaitan dengan gerak (tari) menjadi faktor penentu berhasilnya sebuah karya tari dalam berkomunikasi dengan penontonnya. Kajian ini bertujuan untuk membahas penggunaan desain atas (air design), sebagai salah satu penambah nilai estetik dalam sebuah pertunjukan karya tari; melalui desain-desain ini penari dapat menonjolkan watak/karakter tertentu serta dapat membangkitkan suatu perasaan emosional tertentu bagi penontonnya. Dalam pembahasannya digunakan konsep La Meri mengenai jenis-jenis desain atas (air design) dan sifat-sifatnya.
\end{abstract}

\section{Kata kunci: desain atas, dimensi estetik, pertunjukan karya tari}

\section{A. PENDAHULUAN}

Tari adalah ekspresi manusia yang paling dasar dan paling tua. Melalui tubuhnya, manusia memikirkan dan merasakan ketegangan dan ritme-ritme alam sekitarnya, dan selanjutnya menggunakan tubuh sebagai instrumen, ia mengekspresikan respons-respons perasaannya kepada alam sekitar. Melalui struktur persepsi-persepsi dan perasaannya ia menciptakan tari. Melalui tarinya ia dapat berhubungan dengan sesamanya dan dunianya. Sebagai karya seni, tari memiliki satu kekuatan komunikatif yang terdapat di dalamnya. Hal ini dapat diketahui karena gerak manusia sebagai materi tari adalah suatu esensi dari kehidupan, merefleksikan kehidupan, dan kehidupan itu sendiri. Tarian yang sempurna dianggap sebagai suatu bentuk yang mempunyai kesatuan dan memberikan ilusi "hidup". Kekuatan magic dan komunikatif dari tari kemudian 
muncul melalui sajian bentuk utuh daripada elemen-elemen tari. Tarian sebagai karya seni disusun dan mencapai bentuk yang mampu melibatkan penonton dari awal sampai akhir.

Ada pendapat bahwa tari haruslah tersusun dari gerakan-gerakan tubuh yang indah dan berirama. Tari bukan saja harus indah dan berirama, tetapi sekaligus harus merupakan ekspresi jiwa dari pelakunya. Tari sebagai sebuah produk karya seni, apapun jenis dan bentuknya tentunya akan mengandung suatu nilai keindahan. Nilai keindahan ini seyogyanya dihadirkan dalam setiap penampilan karya tari, sehingga tidak ada kesan bahwa sajian sebuah karya tari bukan hanya sekedar bentuk rangkaian gerak tubuh semata. Salah satu hal yang membuat penikmat tari dapat merasakan keindahan sebuah gerak tari adalah ketika pelakunya (penari) mampu menarikan dengan kekuatan, kelenturan, keseimbangan, dan koordinasi yang sempurna sehingga rasa gerak yang dilakukan dapat dirasakan oleh penonton. Esensi dan makna gerak menjadi jiwa dunia tari dan manusianya sehingga segala hal yang berkaitan dengan gerak (tari) menjadi faktor penentu berhasilnya sebuah karya tari dalam berkomunikasi dengan penontonnya.

Dari pernyataan tersebut, dapat dipahami bahwa penari merupakan faktor penting dalam keberhasilan sebuah pertunjukan tari karena lewat tubuh penarilah karya tari itu akan berkomunikasi dengan penontonnya. Bagi penata tari (koreografer), penari merupakan materi plastis yang sangat berharga sebab dengan penari-penari yang cemerlang atau dengan alat ekspresi yang baik, maka ide seorang penata tari akan dapat diwujudkan secara gemilang juga. Prinsip-prinsip tari sebagai ungkapan suatu keadaan sesunguhnya dapat dikatakan sebagai suatu komunikasi estetik melalui bahasa gerak. Dengan demikian gerak dalam tari adalah bahasa simbolik sebagai media komunikasi antara pencipta tari dengan penonton atau penghayatnya.

Gerak di dalam tari mengandung ide/gagasan yang sesungguhnya akan dikomunikasikan kepada penonton. Ide/gagasan tersebut ditata dan diurai kedalam alur dramatik yang kemudian dialih-bahasakan menjadi alur rasa, suasana yang ini akan dituangkan menjadi frase-frase gerak. (Wahyudianto, 2008:25). Bahasa gerak yang kemudian menjad sajian tari 
merupakan komunikasi estetik melalui saluran-saluran unsur-unsur gerak yang kemudian diberi bentuk khas sebagai tari. Penonton di dalam memahami ide estetik terutama menggunakan indera penglihatan dan pendengaran, penonton dibantu oleh pengalaman hidupnya sebagai pemahaman atas realitasrealitas yang terkait dengan yang sedang ditonton, sedangkan gagasan yang informatif tersebut sebagai alat bantu untuk memberi pemahaman menyeluruh atas bahasa estetik sehingga sebagai sebuah komunikasi, sajian tari merupakan simbol-simbol gagasan yang terwujud dalam bahasa gerak (Wahyudianto, 2008:25).

Salah satu desain gerak yang berperan penting sebagai penambah nilai estetika dalam pertunjukan sebuah karya tari adalah desain atas (air design), yang merupakan desain yang membentuk pola di atas lantai dan terbentuk dari anggota badan si penari (Nursantara, 2007:136). Desain atas, yang juga lazim disebut dengan tata atas, yaitu beragam garis/bentuk dan perubahannya yang disajikan oleh gerak dan pose anggota badan maupun perlengkapan/properti penari dalam kerangka ruang di atas lantai. Beragam garis/bentuk tersebut bisa saja dibentuk/dibuat oleh kaki, badan/torso, lengan, tangan beserta jari jemarinya, kepala, perlengkapan tari (properti), atau dalam perpaduannya (Patria, dkk, 2007: 81). Ada beberapa ragam desain atas yang dikenal dalam tari, diantaranya desain datar, desain dalam, desain vertikal, desain horisontal, desain kontras, desain murni, desain statis, desain lengkung, desain bersudut, desain spiral, desain tinggi, dan sebagainya.

\section{B. METODE PENELITIAN}

Metode penelitian adalah cara-cara yang mengatur prosedur penelitian ilmiah pada umumnya . Metode dalam penelitian ini menggunakan metode deskriptif kualitatif. Menurut Strauss dan Corbin (dalam Sujarweni, 2014:6), penelitian kualitatif adalah jenis penelitian yang menghasilkan penemuan-penemuan yang tidak dapat dicapai (diperoleh) dengan menggunakan prosedur statistik atau cara-cara lain dari kuantifikasi (pengukuran). Dengan pendekatan kualitatif diharapkan mampu menghasilkan uraian yang mendalam tentang ucapan, tulisan, dan perilaku yang dapat diamati dari suatu individu, kelompok, masyarakat, dan organisasi 
tertentu dalam suatu keadaan konteks tertentu yang dikaji dari sudut pandang yang utuh, komprehensif, dan holistik. Melalui pendekatan kualiltatif, penelitian ini bertujuan untuk mengungkap makna dibalik fenomena/gejala yang sedang diteliti, tanpa merubah objek penelitian baik sebelum atau sesudah diadakan penelitian; dalam hal ini akan mendeskripsikan jenis-jenis desain atas (air design) beserta sifat-sifatnya, sebagai salah satu unsur nilai estetik dalam sebuah pertunjukan karya tari.

\section{PEMBAHASAN}

Dalam tari, gerak digunakan untuk tujuan-tujuan ekspresif dan estetis, meskipun peralatan fisiknya sama seperti gerakan berfaedah. Perbedaan antara gerak estetis dan gerak berfaedah terletak pada motivasi yang mengatur tindakan dalam proses dan dalam sifatsifat emosional yang melingkupi aksi/tindakan (Hadi, 2003: 91). Secara garis besar ada dua bagian pokok dalam teknik tata tari, yaitu tata lantai dan tata atas/air design, dimana dalam kajian ini akan dibahas mengenai desain atas dan penggunannya dalam tari. Dalam teori komposisi tari terdapat beberapa desain atas (air design), salah satunya adalah teori La Meri (dalam Rustiyanti,
2010:169), yang menguraikan tentang jenis desain atas (air desain), dimana masing-masing memiliki karakteristik dan penggunaannya sesuai dengan genre tarinya. Adapun desain-desain tersebut diantaranya adalah sebagai berikut:

1) Desain Datar/rata, merupakan desain gerak yang mengutamakan tampilan dari sudut pandang, biasanya sudut pandang yang dijadikan patokan adalah pandangan muka. Postur tubuh penari yang dilihat oleh penonton hampir tanpa perspektif. Desain ini mempunyai sifat/kesan ketenangan, keterbukaan, kejujuran, sederhana. Tarian yang ditampilkan dengan desain datar/rata terkesan seperti gambar pada sebuah papan/selembar kertas yang datar. Contoh sederhana desain ini terdapat pada pertunjukan wayang kulit, dimana bentuk wayang kulit adalah datar/pipih,dibentuk dari selembar kulit yang dipahat sehingga membentuk sosok tokoh pewayangan; memiliki dimensi panjang dan lebar saja, sehingga hanya dapat dilihat dari satu arah saja. Dalam pertunjukan karya tari, desain datar/rata dapat dilakukan oleh penari dengan gerak tubuh dengan (dua) dimensi, dimana gerak yang dilakukan hanya ke arah samping kanan dan kiri 
(horisontal), tanpa merubah arah hadap penari.

2) Desain Dalam, desain ini disamping mempertimbangkan tampilan muka, juga memperhitungkan pengaruh yang ditimbulkan faktor kedalaman. Tubuh penari bila dilihat dari arah penonton tampak memiliki kedalaman (perspektif) atau ruang. Gerak lengan tangan, kaki yang diarahkan ke semua arah akan membentuk/membangun kedalaman. Sifat/kesan yang ditimbulkan oleh desain dalam adalah perasaan/emosi yang dalam. Desain dalam menyajikan tampilan yang berwawasan ruang tiga dimensi, desain ini banyak digunakan dalam sajian tarian yang dipentaskan diatas panggung, misalnya sendratari Ramayana. Bentuk gerak tari dalam desain dalam ini misalnya gerak kesamping kanan-kiri, kemudian bergerak kedepan-belakang, atau gerak berputar (mengelilingi area pentas).

3) Desain Vertikal, yaitu desain tampilan yang menggunakan anggota badan berdiri tegak di atas pokok tungkai, serta lengan menjulur ke atas atau terjuntai ke bawah, artinya penari membentuk/bergerak ke atas dan ke bawah. Desain ini mempunyai sifat/kesan memberi rasa menjangkau ke atas/ke bawah, egosentris, pasrah/menyerah. Desain vertikal umumnya terdapat pada tari-tarian pemujaan yang tidak jauh dari ungkapan kepasrahan atau pergulatan pribadi di hadapan Sang Pencipta. Bentuk gerak tari yang menggunakan desain vertikal misalnya gerak yang menggambarkan permohonan kepada Tuhan, dengan tangan dan muka menengadah keatas seolah-olah memohon/mengharapkan sesuatu dari sang Khalik.

4) Desain Horizontal, adalah desain yang menggunakan sebagian besar anggota badan (tangan, kaki, serta kepala), mengarah kepada garis horisontal. Postur dengan anggota badan membentuk garis melintang. Desain ini mempunyai kesan/sifat lugas, tulus, lapang, terbuka, ekspresif/mencurahkan. Desain horisontal biasanya ditemui pada tari-tarian pergaulan terutama yang menggambarkan sepasang kekasih saat saling menyambut/menerima setelah sekian lama berpisah. Bentuk gerak tari yang menggunakan desain horizontal misalnya gerak tari berpasangan (lakilaki dan perempuan), yang menggambarkan pertemuan antara 2 orang, satu orang berada pada posisi tepi pentas samping kanan,dan satu orang berada pada posisi tepi pentas 
samping kiri, kemudian saling mendekat ke tengah pentas, kemudian mereka melakukan gerak-gerak dengan garis tubuh kesamping kanan dan kiri.

5) Desain Kontras, merupakan desain yang menggunakan garis-garis silang dari anggota badan berbeda. Pasangan garis anggota-anggota badan yang bersilangan tersebut akan akan bertemu pada satu titik bila dilanjutkan gerak anggota badan sang penari, dan akan saling menyambung dan menguatkan. Postur yang menggarap garis-garis bersilang pada lekukan-lekukan yang berlawanan dan mengandung suatu kontinuitas garis dalam oposisi. Desain ini memberikan kesan/sifat kokoh, bertenaga/kekuatan, namun kadangkala juga membingungkan. Desain ini biasanya dibuat untuk tari yang bertema perang, misalnya pada saat gerak langkah kaki seorang penari tarian perang saat melangkah sambil mengacungkan senjata keatas, atau gerakan silangan tangan penari diatas kepala saat menampilkan gerak menangkis serangan musuh. Bentuk gerak tari dengan menggunakan desain kontras ini misalnya gerak penari yang memerankan seorang ksatria/prajurit sedang mengendap-endap dengan langkah maju/mundur dengan teknik menyilangkan kaki, atau gerak 2 penari yang saling adu senjata dengan posisi saling menangkis senjata menyilangkan tangan diatas kepala.

6) Desain Murni, dengan postur tanpa garis-garis yang kontras. Desain ini biasanya dilakukan oleh para penari perempuan yang hendak menampilkan kesan tenang, halus, dan lambat. Gerakan-gerakan dalam desain murni sangat jauh kemungkinannya untuk menampilkan garis-garis anggota badan yang sifatnya kontras. Desain murni lebih cenderung menampilkan gerakan/garisgaris anggota badan yang natural, mengalir, lentur, dan lugas. Bentuk gerak tari dengan dengan menggunakan desain murni misalnya tari sambut/penyambutan yang menggunakaan gerak dengan tempo cenderung lambat, mengalir/mengalun, dengan pola lantai yang cenderung tidak banyak mengalami perubahan.

7) Desain Statis, adalah desain yang dibangun dengan pose-pose anggota badan yang sama walaupun anggota badan lainnya bergerak, misalnya pose lengan penari tetap berada di pinggang terus-menerus sementara kaki penari bergerak ke semua arah. Desain statis dilakukan dengan 'menahan' beberapa 
anggota badan sementara beberapa anggota yang lain terus bergerak, desain ini memberi kesan adanya dua hal yang berbeda. Beberapa anggota badan yang 'ditahan' menampilkan sesuatu yang diam/tidak bergerakatau memiliki gerakan yang berbeda dengan sang penari, misalnya gerakan penari saat 'menahan' telapak tangannya didepan mukanya sementara kepalanya menggeleng kekiri dan kekanan, gerakan tersebut menampilkan adanya sesuatu yang berada di hadapan penari dan menahan pandangannya. Garis dalam desain statis memberi rasa teratur dan berisi. Desain statis kebanyakan digunakan pada tarian daerah Timur yang digarap atas garis statis berupa seri dari pose-pose yang mengalir disisipi garis terlukis dan kualitas dinamis, dimana tekanan dinamika tersebut dapat mengimbaskan kesan ambisi dan nafsu. Bentuk gerak tari dengan menggunakan desain statis misalnya gerak tari Tor-tor dimana kedua kaki berdiri tegak, sementara kedua tangan dengan gerak sembah di depan dada sambil memutar torso badan kekanan-tengah-kiri; kaki tidak berubah posisi, hanya badan sedikit dinaik-turunkan mengikuti gerak tangan.

8) Desain Simetris, adalah desain yang dibangun dengan menempatkan garis- garis anggota badan kanan dan kiri berlawanan arah tetapi berbentuk sama, misalnya tangan kanan mengarah kesamping kanan, siku terlipat $90^{\circ}$ dan jari-jari mengarah keatas, maka tangan kiri juga mengarah kesamping kiri dengan siku terlipat $90^{\circ}$ dan jari-jari mengarah keatas. Desain jenis ini basanya menampilkan kesan/sifat kesedarhanaan, kekokohan, dan ketenangan, namun bila desain gerak ini terlalu banyak dalam suatu karya tari maka tarian tersebut kemungkinan besar akan menjadi sangat membosankan. Dalam karya tari kelompok, kesan kesederhanaan kekokohan, dan ketenangan menjadi semakin kuat bila disertai tata berimbang (balanced) maupun tata serempak (unison). Bentuk gerak tari dengan menggunakan desain simetris ini misalnya posisi kedua kaki brjalan berputar, kedua tangan merentang kekanan dan kekiri (gerak yang menggambarkaan burung terbang), atau gerak tari kecak, dengan posisi duduk kedua tangan diangkat keatas (melambai-lambai).

9) Desain Asimetris, berbalik dengan desain simetris, dibangun dengan cara meletakkan garis-garis anggota badan antara kiri dan kanan secara berlainan. Dengan adanya perbedaan tersebut 
maka garis-garis yang terangkai akan lebih menampilkan suatu yang menarik dan terkesan lebih dinamis, walaupun jenis desain ini kurang menampilkan kesan kekokohan, namun banyak dihadirkan guna membangun suasana yang lebih hangat (dinamis) dan menarik perhatian penonton. Bentuk gerak tari dengan menggunakan desain asimetris ini misalnya gerak kaki berputar, tangan kiri diangkat keatas dan tangan kanan diangkat kesamping kanan, atau kaki kiri berdiri tegak, tangan kiri diangkat keatas, kaki kanan diangkat kesamping (tungkai ditekuk 90derajat), tangan kanan diangkat kesamping kanan.

10) Desain Spiral, adalah desain yang dibangun dengan gerakan yang melingkar yang lebih dari satu lingkaran dan searah dengan sumbu pada pinggang atau kaki penari. Gerakan melingkar dapat dilakukan oleh anggota badan, tangan, kaki, atau bahkan dengan tubuh (torso) penari. Desain spiral juga menampilkan rangkaian gerakan dengan garis-garis lengkung yang jika dirangkaikan membentuk spiral entah secara vertikal (atas-bawah) maupun horisontal (depan-belakang/kirikanan). Desain jenis ini mempunyai kesan/sifat lembut dan berkesinambungan. Bentuk gerak tari dengan menggunakan desain spiral, misalnya pada tarian anak 'hula hop' yang memutar-mutarkan lingkaran bambu di pinggangnya (desain spiral dibentuk oleh bagian torso), atau kedua kaki berdiri tegak berjinjit, kemudian perlahan-lahan, kedua kaki memutarr soiral, badan turun perlahan-lahan sampai pada posisi akhir badan berjongkok.

11) Desain Bersudut, adalah desain yang dibangun dengan sudut-sudut ruang yang dibentuk dari tekukantekukan sendi-sendi tangan dan kaki penari (lutut, siku, pergelangan tangan/kaki). Desain ini mempunyai kesan/sifat kuat dan kokoh. Desain ini dapat dilihat pada bentuk kaki dan lengan para penari perang, dimana posepose yang mereka tampilkan sangat mirip dengan ragam pose kuda-kuda pada seni bela diri. Bentuk gerak tari dengan menggunakan desain bersudut ini misalnya mengangkat kaki kanan/kaki kiri kesamping, tungkai ditekuk 90 derajat (desain bersudut dibentuk oleh tekukan kaki), atau gerak mengangkat tangan kesamping, dengan siku ditekuk keatas atau kebawah 90 derajat (desain bersudut dibentuk oleh tekukan tangan). 
12) Desain/garis tertunda (delayed), adalah garis yang terlukis di udara oleh busana, rambut, atau properti, karena imbas gerak di luar motorik tapi terkontrol oleh kesadaran penari; pose maupun gerak yang masih sangat dipengaruhi oleh beberapa rangkaian sebelumnya. Sementara ada suatu gerak lain ditampilkan, gerak sebelumnya masih tampak jelas hadir meskipun tidak secara eksplisit dihadirkan. Bentuk gerak tari dengan menggunakan desain/garis tertunda (delayed) ini misalnya gerakan yang menggambarkan keterpelantingan dan jatuh sebagai akibat benturan yang keras saat beradu kekuatan antara dua penari perang sering menggunakan desain jenis ini. Dalam gerak tersebut kekuatan yang disebabkan oleh adanya benturan masih tergambar jelas arahnya. Dalam contoh ini proses keterpelantingan dan jatuh diwarnai oleh 'gerakan/aliran' tenaga yang terjadi pada rangkaian tata gerak sebelumnya. Intinya bahwa, desain ini menunjukan proses sebuah penggambaran gerakan bermakna (maknawi), yang menghubungkan antara gerak satu dengan gerak selanjutnya (gerak sebabakibat).

13) Desain/garis terlukis, adalah desain yang dibangun dari gerakan tangan atau anggota badan atau properti yang digunakan penari untuk melukiskan sesuatu, berupa serangkaian gerak yang menggambarkan suatu pesan yang hendak diekspresikan. Bentuk gerak yang menggunakan desain ini misalnya gerakan menanam padi yang melukiskan kegiatan dan jerih payah para petani padi, yang ditunjukkan lewat gerakan tangan penari (tanpa properti), atau gerakan memetik padi yang ditunjukkan penari dengan menggunakan properti.; atau misalnya penari yang melukiskan angkasa dengan menggerakkan kedua tangan dengan gerakan lengkung bergantian.

14) Desain Tinggi, adalah desain yang dibangun dengan gerak bagian atas badan mulai dari bagian dada keatas (ruang diatas bahu). Sesuai dengan sifatnya, aksen gerak yang dibuat pada bagian ini dapat menghasilkan sentuhan intelektual dan spiritual yang kuat. Kepanikan pikiran biasa disajikan dengan 'kerumitan' gerakan yang dilakukan di level atas/tinggi. Tarian pemujaan sedikit menggunakan anggota bagian bawah, tapi efek dapat diatur atau dimanusiakan dengan memberikan tekanan gerak pada tubuh bagian ini. Desain tinggi biasanya banyak dijumpai pada tari-tarian pemujaan, seperti tari- 
tarian di Bali. Bentuk gerak tari yang menggunakan desain tinggi misalnya pada tari Kecak (dari Bali), yang menggunakan anggota tubuh bagian atas untuk menggambarkan permintaan kepada dewa dengan cara menggerakkan bahu maupun tangan yang diangkat keatas seolah-olah menengadah keatas mengharapkan sesuatu.

15) Desain Rendah, adalah desain yang dibangun dari gerakan-gerakan tubuh penari dari pinggang hingga telapak kaki. Arah gerakan berkisar antara pinggang hingga lantai pentas. Aksen gerak pada tubuh bagian bawah ini dapat memberikan gairah dan penuh daya hidup, karenanya desain rendah ini banyak dijumpai pada tarian perang. Bentuk gerak tari yang menggunakan desain rendah ini misalnya gerak dua penari yang menggambarkan dua orang musuh yang saling berhadapan untuk mengadu kekuatan (kesaktian). Adegan semacam ini pada umumnya menonjolkan gerakan kaki (kuda-kuda) untuk menunjukkan kesaktian masingmasing, atau dalam proses perkelahian, kadang-kadang juga melakukan gerakan berguling di tanah.

\section{D.SIMPULAN}

Gerak di dalam tari mengandung ide/gagasan yang sesungguhnya akan dikomunikasikan kepada penonton. Bahasa gerak yang kemudian menjad sajian tari merupakan komunikasi estetik melalui saluran-saluran unsur-unsur gerak yang kemudian diberi bentuk khas sebagai tari. Gagasan yang informatif tersebut sebagai alat bantu untuk memberi pemahaman menyeluruh atas bahasa estetik sehingga sebagai sebuah komunikasi, sajian tari merupakan simbol-simbol gagasan yang terwujud dalam bahasa gerak.

Penggunaan desain atas (air design) berperan penting sebagai penambah nilai estetik dalam pertunjukan sebuah karya tari. Berdasarkan konsep La Meri, ada beberapa ragam desain atas yang dikenal dalam tari, diantaranya desain datar, desain dalam, desain vertikal, desain horisontal, desain kontras, desain murni, desain statis, desain lengkung, desain bersudut, desain spiral, desain tinggi, dan sebagainya. Dengan mengetahui jenis dan sifat dari desaindesain atas (air design), diharapkan para pekerja seni (tari: seniman tari, penari, 
koreografer dll), dapat membuat karya

datang.

tari dengan lebih baik dimasa yang akan

\section{DAFTAR PUSTAKA}

Hadi, Y. Sumandiyo. 2003. Mencipta Lewat Tari. Yogyakarta: Manthili Nursantara, Yayat. 2007. Seni Budaya Untuk SMA. Jakarta: Penerbit Erlangga

Patria, Eyri. 2005. Cinta Seni Budaya. Bekasi: PT. Galaxy Puspa Mega

Rustiyanti, Sri. 2010. Menyingkap Seni Pertunjukan Etnik di Indonesia.

Bandung: Sunan Ambu Press

Sujarweni, V. Wiratna. 2014. Metodologi Penelitian. Yogyakarta: Pustaka Baru Press

Wahyudianto. 2008. Pengetahuan Tari. Solo: ISI Press Solo 


\section{KETENTUAN PENULISAN ARTIKEL JURNAL SITAKARA}

1. Naskah berbahasa Indonesia bertemakan Seni Budaya yang meliputi hasil penelitian pengajaran seni budaya, cabang seni, dan kebudayaan.

2. Naskah harus asli dan belum pernah dimuat dalam media lain. Naskah dapat berupa hasil penelitian perorangan atau kelompok. Naskah ditulis dengan cara-cara yang sesuai dengan ketentuan penulisan artikel ilmiah menggunakan bahasa Indonesia yang baku, berupa ketikan, beserta soft line dalam CD-RW atau dengan mengirimkan email pada redaksi Jurnal Sitakara dengan alamat email: jurnalsitakarasendratasik@yahoo.com, spasi 1,5 jenis huruf Arrial Narrow ukuran 12, dengan panjang naskah antara 8-15 halaman pada kertas A4.

3. Artikel hasil penelitian memuat:

JUDUL

NAMA PENULIS

ABSTRAK

\section{A. PENDAHULUAN}

B. METODE PENELITIAN

C. HASIL DAN PEMBAHASAN

D. SIMPULAN

4. Artikel kajian konseptual memuat JUDUL

NAMA PENULIS

ABSTRAK

PENDAHULUAN

SUB JUDUL

SIMPULAN

DAFTAR PUSTAKA

\section{: XXX (HURUF KAPITAL)}

: (disertai jabatan dan institusi)

: (Bahasa Indonesia yang memuat 100- 150 kata diikuti kata kunci, dengan jenis huruf Arrial Narrow dan ukuran huruf 11 serta dicetak tebal).

: (Memuat latar belakang masalah, tinjauan pustaka Secara ringkas, masalah dan tujuan penelitian).

: (Berisi simpulan)

: XXX (HURUF KAPITAL)

: (disertai jabatan dan institusi)

: (Bahasa Indonesia yang memuat 100- 150 kata diikuti kata kunci, dengan jenis huruf Arrial Narrow dan ukuran huruf 11 serta dicetak miring)

: (Memuat latar belakang masalah, tinjauan pustaka secara ringkas, masalah penelitian dan tujuan penelitian)

: Sesuai dengan kebutuhan (tanpa numbering)

: (Berisi simpulan dan saran)

: (Berisi pustaka yang dirujuk dalam uraian naskah) 
5. Referensi sumber dalam teks artikel ditulis dengan menggunakan side note, contoh: (Jalalluddin, 1991:79); (Taufik, 2005;350); (Hamid dan Madjid, 2011:43). Sementara penulisan daftar pustaka disusun dengan ketentuan. Nama Pengarang. Tahun Terbit. Judul (dicetak miring). Kota Terbit: Nama Penerbit. Contoh: Koentjaraningrat. 2010. Manusia dan Kebudayaan Di Indonesia. Jakarta: Djambatan.

Daftar pustaka hanya memuat pustaka/sumber yang dirujuk dalam uraian dan disusun menurut abjad, tanpa nomor urut.

6. Naskah yang dimuat akan disunting kembali oleh redaksi tanpa mengubah isinya.

7. Naskah yang ditolak (tidak bisa dimuat) akan dikirim kembali ke penulis dengan pemberitahuan tertulis dari redaksi atau alamat email.

8. Penulis yang naskahnya dimuat akan mendapatkan 1 (satu) majalah nomor yang bersangkutan.

9. Contact Person: Treny (085357344704) dan Mainur (081373165553). 